\title{
Model Optimisasi Robust untuk Mengatasi Ketidaktentuan Estimasi Durasi Operasi pada Masalah Penjadwalan Ruang Operasi Rumah Sakit
}

\author{
Diah Chaerani $^{*}$, Ija Royana ${ }^{1}$, Elis Hertini ${ }^{1}$
}

\begin{abstract}
The problem of operating room scheduling in hospitals is a matter of diversity in duration of operation that requires scheduling to reduce the level of busyness of the operating room. Operating room scheduling is how to put patients into optimally available operating room blocks to minimize patient waiting time. This problem is presented in integer linear programming (ILP) formulation. In this paper, a discussion on how to model the uncertain operating room scheduling problem using Robust Optimization (RO) is presented. In RO methodology, it is introduced Robust counterpart (RC) methodology, i.e., a methodology that can be used to model what so-called robust counterpart of the uncertain optimization model for operating room scheduling problem. By choosing uncertainty box sets and ellipsoidal uncertainty, the modeling results show that the obtained $\mathrm{RC}$ model for the uncertain operating room scheduling problems belongs to the class of computationally tractable problems, in which it is linear programming for box uncertainty set and conic quadratic programming for ellipsoidal uncertainty set with binary variables involved. In this paper, example is presented using software Maple.
\end{abstract}

Keywords: Scheduling of operating rooms; robust optimization; uncertain estimated duration; robust counterpart.

\section{Introduction}

Jasa pelayanan kesehatan adalah sistem yang berubah dan berkembang dengan cepat, industri kesehatan tersebut berusaha untuk menemukan cara yang tepat untuk terus menyesuaikan dengan perkembangan (lihat Barnes et al. [1]). Rumah sakit dalam fungsinya sebagai penyedia jasa pelayanan kesehatan masyarakat memiliki bagian yang mendukung dalam sebuah sistem rumah sakit seperti bagian pelayanan rawat inap, pelayanan rawat jalan, instalasi gawat darurat, instalasi bedah sentral sebagai pelayanan operasi, dan lain sebagainya. Bagian pelayanan operasi di rumah sakit merupakan hal yang krusial yang memerlukan perhatian lebih terkait keselamatan pasien.

Masalah penjadwalan dan perencanaan ruang operasi merupakan masalah komplikasi lanjut oleh keragaman durasi operasi yang memaksa perencana harus melakukan penjadwalan dengan lebih konservatif agar tingkat utilisasi ruang operasi berkurang (Tyler et al. [2]). Perencanaan ruang operasi yang buruk berpengaruh terhadap angka waktu tunggu dan waktu lembur.

\footnotetext{
${ }^{1}$ Fakultas Matematika dan Ilmu Pengetahuan Alam, Jurusan Matematika, Universitas Padjajaran, Jl. Raya Bandung Sumedang, KM.21 Jatinangor, Sumedang 45363.

Email: d.chaerani@unpad.ac.id; ijaroyana@gmail.com, elis.hertini@ unpad.ac.id

* Penulis korespondensi
}

Angka waktu tunggu yang tinggi berpengaruh terhadap kondisi kesehatan pasien dan tingkat kepuasan pasien terhadap pelayanan rumah sakit, dan angka waktu lembur yang tinggi pun berpengaruh terhadap performa layanan yang diberikan petugas operasi. Oleh sebab itu, dibutuhkan perencanaan ruang operasi yakni mengenai penentuan penggunaan ruang operasi terkait penjadwalan dan alokasi kapasitas ruang operasi yang tersedia.

Menurut Weiss [3], ruang operasi terdiri dari dua macam yakni blocked rooms dan open posting rooms seperti dapat dilihat pada Gambar 1 yang menunjukkan simulasi yang membedakan antara keduanya. Pada makalah ini, diasumsikan bahwa ruang operasi yang digunakan adalah blocked room.

Merujuk pada (Addis et al. [4]), penjadwalan penggunaan ruang operasi secara umum terbagi menjadi tiga strategi, yaitu penjadwalan blok, penjadwalan terbuka, dan penjadwalan modifikasi blok. Pada penjadwalan blok, perencanaan penggunaan ruang operasi dengan mengalokasikan waktu tetap pada hari tertentu untuk dokter bedah atau spesialisasi tertentu. Pada penjadwalan terbuka, tidak memberikan alokasi khusus untuk spesialisasi tertentu sehingga penggunaan ruang operasi menerapkan metode first-come, first-served. Penjadwalan modifikasi blok merupakan gabungan antara penjadwalan blok dan penjadwalan terbuka. Dibandingkan dengan penjadwalan terbuka dan modifikasi blok, 
perencanaan ruang operasi menggunakan strategi penjadwalan blok karena strategi tersebut memiliki keuntungan yakni keteraturan jadwal dan kepastian alokasi penggunaan ruang operasi untuk suatu permintaan operasi.
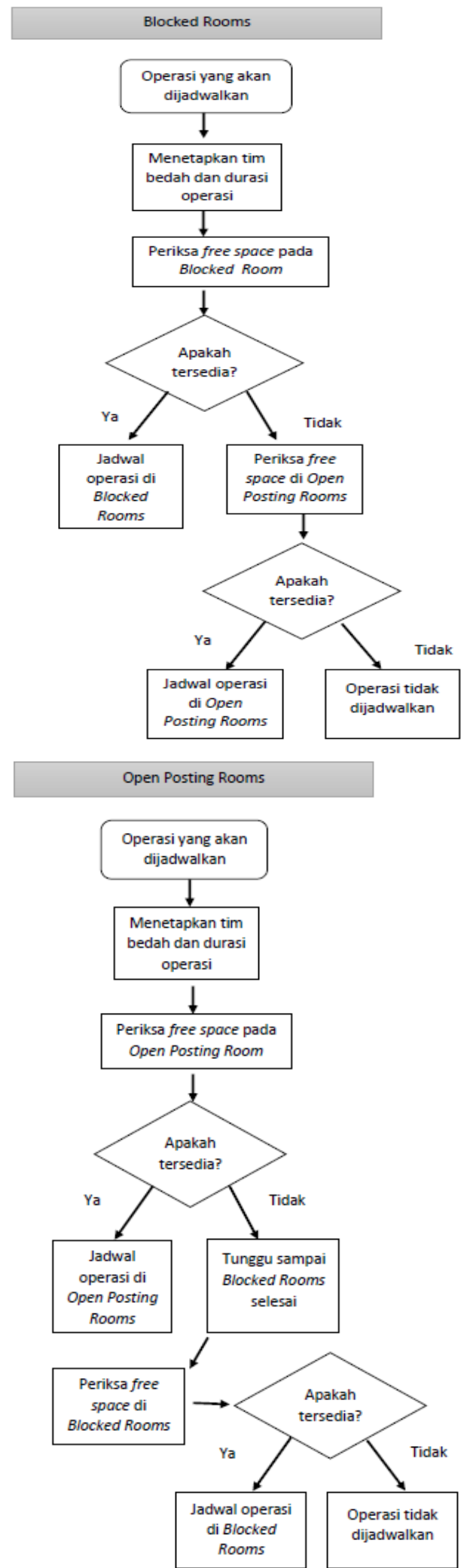

Gambar 1. Simulasi block rooms dan open posting rooms (Weiss [3])
Untuk menggambarkan pentingnya masalah ini, beberapa literatur yang sudah dipublikasikan mengenai perencanaan ruang operasi antara lain Denton et al., [5] yang membahas mengenai masalah advanced schedulling dengan ketidaktentuan menggunakan dua tahap model stokastik dimana fungsi tujuan melibatkan waktu tunggu pasien, waktu lembur dan waktu menganggur ruang operasi. Model lain, dengan menggunakan pemrograman stokastik dibahas oleh Min dan Yih [6] dengan cara metode penaksiran rata-rata sampel untuk mendapatkan jadwal operasi optimal dengan tujuan meminimumkan biaya pasien dan biaya waktu lembur ruang operasi yang digunakan.

Terdapat pula, Oostrum et al. [7] yang membahas mengenai model yang bertujuan untuk mengoptimalkan utilisasi ruang operasi tanpa menambah waktu lembur dan pembatalan. Sementara itu, Denton et al. [8] menyajikan dua model yang bertujuan untuk meminimumkan biaya keseluruhan ruang operasi termasuk biaya tetap ruang operasi dan biaya waktu lembur. Hans et al. [9] mengusulkan model optimisasi robust dengan tujuan memaksimumkan utilisasi ruang operasi namun waktu lembur minimum dengan mengenalkan perencanaan waktu slack. Kemudian, Tanfani et al. [10] mengusulkan dua model. Pertama, model mixed integer linear programming (ILP) untuk mendapatkan solusi deterministik untuk masalah perencanaan ruang operasi. Kedua, keragaman durasi operasi didapat agar kendala kesempatan pasien di setiap blok ruang operasi dan solusi optimisasi robust dicapai dengan menambah slack secara iteratif ke dalam solusi model deterministik.

Motivasi utama dalam makalah ini adalah memberikan gambaran mengenai penggunaan teknik optimisasi robust dalam menyelesaian masalah penjadwalan ruang operasi rumah sakit yang melibatkan data taktentu. Optimisasi robust merupakan satu bidang dari optimisasi untuk menyelesaikan masalah yang berkaitan dengan ketidakpastian, kelas masalah optimisasi ini pertama kali diperkenalkan oleh Mulvey et al. [11] pembahasan survey komprehensif dalam bidang optimisasi robust dibahas oleh Gabrel et al. [12].

Merujuk pada model ILP yang diusulkan oleh Addis et al. [4] pembahasan difokuskan pada masalah optimisasi taktentu pada penjadwalan ruang operasi rumah sakit dengan tujuan meminimumkan total waktu tunggu pasien, dalam makalah ini akan digunakan asumsi yang sama, yaitu bahwa data taktentu yang terlibat adalah data durasi operasi. Namun, metode penyelesaian untuk masalah tersebut di atas dilakukan dengan pendekatan yang berbeda. 
Dalam makalah ini, model ILP taktentu yang diusulkan Addis et al. [4] diselesaikan dengan metode robust counterpart (RC) yang diusulkan oleh BenTal dan Nemirovskii (lihat $[13,14,15])$. Sementara pada makalah Addis et al., [4] digunakan pendekatan optimisasi robust seperti yang diusulkan oleh Bertsimas dan Sim (lihat [16,17]), dimana dalam hal ini dilakukan asumsi bahwa ketidaktentuan data hanya terjadi pada beberapa indeks himpunan taktentu yang ditetapkan.

Metode robust counterpart (RC) yang diusulkan oleh BenTal dan Nemirovskii seperti yang dibahas dalam $[13,14,15]$, merupakan salah satu metode yang dikenal untuk menangani ketidaktentuan data dalam suatu masalah optimisasi. Dalam metode ini, ketika data taktentu dilibatkan dalam model yang dibahas, maka formulasi masalah optimisasi yang harus diselesaikan merupakan masalah optimisasi yang semi-infinite, yaitu masalah optimisasi dengan sejumlah variabel hingga dengan fungsi kendala yang tak-hingga banyaknya (lihat Goerigk dan Schöbel [18]).

Merujuk pada Ben-Tal dan Nemirovski [14] dan [15], disebutkan bahwa tantangan utama dalam metode $\mathrm{RC}$ adalah untuk menjawab pertanyaan bagaimana dan kapan suatu formulasi RC dari masalah optimisasi taktentu dapat dinyatakan sebagai suatu masalah optimisasi yang computionally tractable atau paling tidak model RC yang diperoleh dapat didekati sebagai suatu masalah yang tractable. Hal ini sangat bergantung pada bagaimana himpunan taktentu yang dipilih untuk merepresentasikan ketidaktentuan data. Untuk memenuhi hal ini, tantangan tersebut di atas hanya dapat dipenuhi, bila himpunan data taktentu tersebut dapat dipilih dalam suatu cara yang tepat. Kelas masalah yang computationally tractable ini dapat diselesaikan dalam waktu yang polinom serta terjamin eksistensi solusi optimal global karena dapat direpresentasikan dalam salah satu dari tiga kelas masalah optimisasi konveks, yaitu masalah optimisasi linear, optimisasi conic quadratic atau semidefinite optimisasi. Merujuk pada Ben-Tal et al., [15], pencapaian formulasi yang robust tersebut dapat dilakukan ketika himpunan data taktentu diasumsikan berada dalam tiga himpunan yang dianyatakan sebagai himpunan tak tentu yang berupa box, ellipsoidal atau polihedral (lihat Ben-Tal et al. [15], Gorissen et al. [19], Hertog et al. [20]).

Dalam makalah ini dilakukan pemodelan optimisasi robust dengan menggunakan metode $\mathrm{RC}$ pada masalah penjadwalan ruang operasi dengan asumsi ketidaktentuan pada data estimasi durasi operasi. Pada bagian paparan hasil dan pembahasan ditunjukkan bahwa model optimisasi robust counterpart yang diperoleh untuk masalah optimisasi taktentu penjadwalan ruang operasi merupakan linear optimisasi yang melibatkan variabel biner untuk kasus data box uncertainty dan merupakan conic quadratic optimisasi dengan variabel biner untuk kasus data ellipsoidal uncertainty. Hal ini sesuai dengan tujuan penerapan metode RC. Keterlibatan variable biner pada kedua formulasi RC ditangani dengan penerapan Metode Branch and Bound untuk penyelesaian variabel biner merujuk pada Wolsey [21]. Perhitungan untuk contoh kasus dilakukan dengan bantuan software Maple.

\section{Metode Penelitian}

Pada sub bagian ini dibahas secara ringkas metode penelitian yang digunakan dalam makalah ini, antara lain pembahasan mengenai paradigma optimisasi robust dan cara menyelesaikan robust counterpart seperti yang diperkenalkan (lihat BenTal et al. [15], Chaerani dan Roos [22], Gorissen et al. [19], Hertog et al. [20]). Metode branch and bound untuk menyelesaikan masalah optimisasi linear integer dibahas secara singkat merujuk pada Wosley [21].

\section{Paradigma Optimisasi Robust}

Didefinisikan masalah pemrograman linear sebagai berikut:

$\min _{x}\left\{c^{T} x: A x \leq d\right\}$

Jika parameter $c, A$ dan $d$ diasumsikan bernilai tak tentu, dimana $c, A, d \in \mathcal{U}$, dengan $U$ merupakan himpunan semua ketidakpastian data, maka dari masalah pemrograman linear tersebut dapat diperoleh masalah pemrograman linear tak tentu sebagai berikut:

$\min _{x}\left\{c^{T} x: A x \leq d, x \geq 0 \forall c, A, d \in \mathcal{U}\right\}$

Ben-Tal et al. dalam [15] menyatakan bahwa agar optimisasi robust menghasilkan solusi feasible, maka harus didefinisikan "lingkungan keputusan" yang mempunyai karakteristik sebagai berikut: (A1) Semua variabel keputusan merepresentasikan keputusan "here and now", serta harus didapatkan nilai numerik tertentu sebagai hasil dari penyelesaian masalah sebelum data sebenarnya memperlihatkan nilai sebenarnya. (A2) Pembuat keputusan bertanggungjawab sepenuhnya atas keputusan yang harus dibuat jika dan hanya jika data sebenarnya telah ditentukan dalam himpunan ketidakpastian $\mathcal{U}$. (A3) Kendala pada masalah Pemrograman Linear tak tentu adalah kendala "sulit", artinya tidak dapat ditoleransi pelanggaran dari kendala, meskipun sekecil apapun, ketika data berada pada $u$. 
Menggunakan kondisi A.1, A.2 dan A.3 tersebut di atas, pendekatan optimisasi robust mengkonversi keluarga masalah taktentu (2) menjadi masalah deterministik dengan fungsi variable tunggal berikut, yang disebut sebagai robust counterpart.

$\pi^{*}=\min _{x}\left\{c^{T} x: A x \leq d, x \geq 0 \forall(c, A, d) \in \mathcal{U}\right\}$

Vektor $x^{*}$ disebut solusi optimal robust jika untuk semua realisasi $\forall(c, A, d) \in \mathcal{U}, x^{*}$ merupakan solusi fisibel dan nilai dari fungsi objektif dijamin bernilai paling besar $\pi^{*}$. Menurut Gorissen et al [19] dan Hertog et al. [20], masalah (2) tersebut dapat dinyatakan secara ekivalen sebagai masalah dengan fungsi objektif linear tentu dan kendala tak tentu sebagai berikut:

$\min _{x, t}\left\{t: c^{T} x-t \leq 0, a_{i}^{T} x-d_{i} \leq 0, i=1, \ldots, m\right\}$,

$(c, A, d) \in \mathcal{U}$

Selain asumsi-asumsi dasar tersebut, dapat diasumsikan bahwa fungsi objektif adalah tentu dan kendala pada ruas kanan adalah tentu (Gorissen et al. [19]). Asumsi-asumsi ini tidak membatasi karena hal-hal sebagai berikut: (B1) Misalkan koefisienkoefisien pada fungsi objektif, $c$, tak tentu, dan koefisien-koefisien tersebut dihimpun dalam himpunan $C$ :

$\min _{x} \max _{c \in C}\left\{c^{T} x: A x \leq d, \forall A \in \mathcal{U}\right\}$

Ketidakpastian fungsi objektif dari masalah optimisasi dapat diformulasi kembali secara ekivalen menjadi fungsi objektif tentu berikut (lihat Ben-Tal et al. [15]):

$\min _{x, t}\left\{t: c^{T} x-t \leq 0, \forall c \in C, A x \leq d, \forall A \in \mathcal{U}\right\}$

dengan variabel tambahan $t \in R$.

(B2) Jika vektor ruas kanan $d$ taktentu, maka selalu dapat dibentuk menjadi koefisien tentu dengan memperkenalkan variable tambahan $x_{0}=1$, sehingga diperoleh (Hertog et al. [20]):

$\min _{x}\left\{c^{T} x: a_{i}^{T} x-d_{i} x_{0} \leq 0, i=1, \ldots, m, x_{0}=\right.$ $1, \forall A, d \in \mathcal{U}\}$

(B3) Robustness atas himpunan tak tentu $\mathcal{U}$ dapat diformulasikan dalam bentuk constraints-wise. Menurut Hertog [20], pengertian constraints-wise dari himpunan taktentu $U_{i}$ merupakan proyeksi dari himpunan $\mathcal{U}$ pada bidang dari komponen taktentu dari kendala ke-i. Merujuk pada Ben-Tal et al. [15] telah dibuktikan bahwa secara umum robustness untuk kendala ke- $i$ atas himpunan taktentu $\mathcal{U}$ adalah ekivalen dengan robustness terhadap $U_{i}$. (B4) Ketidaktentuan $\mathcal{U}$ dapat digantikan oleh convex hull, $\operatorname{conv}(\mathcal{U})$, bukti formal dapat dilihat pada BenTal et al. [15] bahwa menguji fisibilitas himpunan taktentu $\mathcal{U}$ ekivalen dengan memaksimumkan fung- si linear atas himpunan taktentu $\mathcal{U}$ yang menghasilkan nilai optimal yang sama jika masalah ini diselesaikan untuk memaksimumkan atas convex hull U. Pada bagian selanjutnya dibahas bagaimana cara menyelesaikan robust counterpart.

\section{Menyelesaikan Robust Counterpart}

Asumsikan $c \in R^{n}$ dan $d \in R^{m}$ adalah tentu, maka formulasi robust dari (2) yaitu robust counterpart adalah sebagai berikut (Gorissen et al., [19]):

$\min _{x}\left\{c^{T} x: A(\zeta) x \leq d, \forall \zeta \in Z\right\}$

$\Leftrightarrow \min _{x}\left\{c^{T} x: a^{T}(\zeta) x \leq d, \forall \zeta \in Z\right\}$

dimana $Z \subset R^{L}$ menunjukkan penggunaan himpunan ketidakpastian tertentu. Solusi $x \in R^{n}$ disebut robust feasible jika memenuhi semua kendala tak tentu $[A(\zeta) x \leq d]$ untuk semua realisasi dari $\zeta \in Z$. Didefinisikan parameter ketidakpastian:

$a(\zeta)=a=\bar{a}+P \zeta$

dimana $\bar{a} \in R^{n}, P \in R^{n \times L}$ dan $\bar{a}$ merupakan nilai nominal. Dapat didefinisikan himpunan $\mathcal{U}$ :

$\mathcal{U}=\{a: a=\bar{a}+P \zeta, \zeta \in Z\}$

Sebuah kendala yang diperoleh dari (9) dengan melakukan substitusi parameter ketidakpastian dapat dimodelkan sebagai berikut:

$(\bar{a}+P \zeta)^{T} x \leq d, \forall \zeta \in Z$

Solusi optimal dari robust counterpart disebut solusi robust optimal, dan nilai optimal dari robust counterpart disebut nilai robust optimal dari masalah pemrograman linear tak tentu.

Merujuk pada Ben-Tal et al. [15], setelah mendefinisikan robust counterpart, maka hal penting yang harus diungkap adalah apakah robust counterpart tersebut memiliki status komputasi yang tractable. Serta kapan robust counterpart dapat diproses secara efisien.

Untuk menjawab pertanyaan tersebut di atas, BenTal et al. [15] telah dibahas bahwa robust counterpart dari suatu masalah optimisasi linear taktentu dengan himpunan taktentu $U$ merupakan masalah yang computationally tractable $\mathcal{U}$ convex dari $\mathcal{U}$ juga merupakan masalah yang computationally tractable. Hal ini dapat dicapai dengan menempuh strategi berikut. Pertama batasi masalah optimisasi linear taktentu dengan suatu fungsi objektif yang tentu. Kedua, nyatakan robust counterpart dalam representasi yang computationally tractable dari satu kendala linear taktentu. Hal ini berarti bahwa formulasikan robust counterpart sebagai masalah minimisasi dari fungsi objektif linear atas 
suatu himpunan kendala konveks yang terbatas. Sehingga formulasi robust counterpart menjadi computationally tractable.

Menurut Ben-Tal et al. [15] untuk menganalisis robust counterpart yang computationally tractable dapat dengan menunjukkan robust counterpart tersebut dapat dibentuk menjadi linear, kendala konik kuadratik, atau semidefinit. Sehingga masalah dapat dikatakan sebagai linear programming (LP), conic quadratic optimization (CQO), atau semidefinite optimization (SDO) seperti dinyatakan dalam Teorema 1.

\section{Teorema 1 (Ben-Tal dan Nemirovski [14])}

Asumsikan himpunan ketidakpastian $u$ pada (2) merupakan affine image dari himpunan terbatas $\mathrm{Z}=\{\zeta\} \subset \mathrm{R}^{\mathrm{N}}$, dan $\mathrm{Z}$ merupakan:

1. Sistem dari kendala pertidaksamaan linear $\mathrm{P} \zeta \leq \mathrm{p}$

2. Sistem dari pertidaksamaan Conic Quadratic $\left\|P_{i} \zeta-p_{i}\right\|_{2} \leq q_{i}^{T} \zeta-r_{i}, i=1, \ldots, M$

3. Sistem dari pertidaksamaan Matriks Linear $\mathrm{P}_{0}+\sum_{\mathrm{i}=1}^{\mathrm{dim} \zeta} \zeta_{\mathrm{i}} \mathrm{P}_{\mathrm{i}} \geq 0$

Pada kasus (ii) dan (iii) juga diasumsikan bahwa sistem dari kendala yang mendefinisikan $\mathcal{U}$ adalah strictly feasible maka robust counterpart (4) dari pemrograman linear tak tentu (2) ekivalen dengan:

1. Masalah pemrograman linear pada kasus (i)

2. Masalah conic quadratic pada kasus (ii)

3. Masalah semidefinit pada kasus (iii)

Bukti: Telah dibahas secara lengkap oleh Ben-Tal dan Nemirovski [14]) dan bentuk pembuktian lainnya dibahas oleh Chaerani dan Roos (lihat [22]). Selanjutnya disajikan pembahasan mengenai bagaimana metode penyelesaian RC dengan Himpunan Box dan Ellipsoidal Uncertainty.

\section{Menyelesaikan Robust Counterpart untuk Himpunan Box Uncertainty dan Ellipsoidal Uncertainty}

Formulasi dari model optimisasi robust counterpart terkait dengan pemilihan himpunan ketidakpastian U. Menurut Gorissen et al. [19], optimisasi robust adalah memberikan pendekatan aman yang tractable dari kendala pada kasus, yaitu formulasi tractable yang menjamin kendala memenuhi:

$x$ memenuhi $a(\zeta)^{T} x \leq d, \forall \zeta \in \mathcal{U}_{\varepsilon}$

$\Rightarrow x$ memenuhi $P_{\zeta}\left(a(\zeta)^{T} x \leq d\right) \geq 1-\varepsilon$

Untuk $\varepsilon=0$, maka kendala merupakan kendala robust klasik. Tantangan yang muncul adalah menentukan himpunan $U_{\varepsilon}$ untuk nilai $\varepsilon$ yang lain. Kasus paling sederhana adalah ketika hanya diketa- hui $\|\zeta\|_{\infty} \leq 1$. Untuk kasus tersebut, himpunan box uncertainty merupakan satu-satunya himpunan yang dapat memberikan jaminan probabilitas (untuk $\varepsilon=0$ ).

Menurut Gorissen et al. [19] sebuah himpunan box uncertainty yang memuat berbagai macam realisasi untuk setiap komponen $\zeta$ merupakan pilihan yang paling robust dan menjamin bahwa kendala tidak pernah dilanggar, tetapi di sisi lain hanya ada kemungkinan kecil semua parameter ketidakpastian mengambil nilai kasus terburuk. Hal ini menyebabkan perkembangan himpunan ketidakpastian yang lebih kecil yang masih menjamin bahwa kendala "hampir tidak pernah" dilanggar, yaitu ellipsoidal uncertainty yang mungkin berpotongan dengan box uncertainty.

Dalam Gorissen et al. [19], dibahas bahwa himpunan box uncertainty dapat dinyatakan sebagai berikut:

$Z=\left\{\|\zeta\|_{\infty} \leq 1\right\}$

Sehingga dapat didefinisikan himpunan $\mathcal{U}$ :

$\mathcal{U}=\left\{a: a=\bar{a}+P \zeta,\|\zeta\|_{\infty} \leq 1\right\}$

Untuk memperoleh formulasi robust counterpart dari himpunan box uncertainty, maka himpunan box uncertainty harus diterapkan pada pertidaksamaan (12) sehingga diperoleh:

$(\bar{a}+P \zeta)^{T} x \leq d, \forall \zeta:\|\zeta\|_{\infty} \leq 1$

$\max _{\zeta:\|\zeta\|_{\infty} \leq 1}(\bar{a}+P \zeta)^{T} x=$

$\bar{a}^{T} x+\max _{\zeta:\|\zeta\|_{\infty} \leq 1}\left(P^{T} x\right)^{T} \zeta \leq d$

Menggunakan sifat norm seperti dapat dirujuk dari Hunter [23] dan Olver [24], norm-1 dari vektor $v=\left(v_{1}, v_{2}, \ldots, v_{n}\right)^{T} \in R^{n} \quad$ didefinisikan sebagai penjumlahan dari nilai absolut setiap anggotanya:

$\|v\|_{1}=\left|v_{1}\right|+\left|v_{2}\right|+\cdots+\left|v_{n}\right|$

Maksimum atau norm- $\infty$ merupakan entri dengan nilai maksimal pada nilai absolutnya:

$\|v\|_{\infty}=\max \left\{\left|v_{1}\right|,\left|v_{2}\right|, \ldots,\left|v_{n}\right|\right\}$

diketahui bahwa:

$\max _{\zeta:\|\zeta\|_{\infty} \leq 1}\left(P^{T} x\right)^{T} \zeta=\max _{\zeta:\left|\zeta_{i}\right| \leq 1} \sum_{i}\left(P^{T} x\right)_{i} \zeta_{i}=$ $\sum_{i}\left|\left(P^{T} x\right)_{i}\right|=\left\|P^{T} x\right\|_{1}$

Berdasarkan persamaan (23) diperoleh formulasi robust counterpart dari persamaan (20) yang ekivalen dengan pertidaksamaan (19):

$\bar{a}^{T} x+\left\|P^{T} x\right\|_{1} \leq d$

Selanjutnya, merujuk kepada Hertog et al. [20], robust counterpart (24) dapat dengan mudah dimodelkan sebagai kendala linear. Hal ini mengaki- 
batkan bahwa robust counterpart memiliki tipe yang sama dengan masalah awal, yaitu kendala linear, meskipun banyak variabel dan kendala bertambah. Robust counterpart dapat ditunjukkan dalam bentuk kendala linear, maka masalah tersebut dapat dikategorikan sebagai masalah pemrograman linear, sehingga robust counterpart dapat dijamin computationally tractable.

Berdasarkan pembahasan yang disajikan oleh Gorissen et al. [19], himpunan ellipsoidal uncertainty dapat dinyatakan sebagai berikut:

$Z=\left\{\|\zeta\|_{2} \leq 1\right\}$

sehingga dapat didefinisikan himpunan $\mathcal{U}$ :

$\mathcal{U}=\left\{a: \bar{a}+P \zeta,\|\zeta\|_{2} \leq 1\right\}$

Untuk memperoleh formulasi robust counterpart dari himpunan ellipsoidal uncertainty, maka himpunan ellipsoidal uncertainty harus diterapkan pada pertidaksamaan (12) sehingga diperoleh:

$(\bar{a}+P \zeta)^{T} x \leq d \forall \zeta:\|\zeta\|_{2} \leq 1$

Pertidaksamaan tersebut ekivalen dengan:

$\max _{\zeta:\|\zeta\|_{2} \leq 1}(\bar{a}+P \zeta)^{T} x=$

$\bar{a}^{T} x+\max _{\zeta:\|\zeta\|_{2} \leq 1}(P x)^{T} \zeta \leq d$

Perhatikan bahwa untuk suatu $x$ maka nilai terbaik pada kasus terburuk untuk pertidaksamaan di atas tercapai ketika dipilih vektor satuan;

$\zeta=\frac{P^{T} x}{\left\|P^{T} x\right\|}$

sehingga

$$
\begin{aligned}
\max _{\zeta:\|\zeta\|_{2} \leq 1}(P x)^{T} \zeta & =\frac{\left(P^{T} x\right)^{T}\left(P^{T} x\right)}{\left\|P^{T} x\right\|}=\frac{\left(P^{T} x\right)^{2}}{\sqrt{\left(P^{T} x\right)^{2}}} \\
=\sqrt{\left(P^{T} x\right)^{2}} & =\left\|P^{T} x\right\|_{2}
\end{aligned}
$$

maka diperoleh formulasi Robust counterpart dari persamaan (28) yang ekivalen dengan pertidaksamaan (27)

$\bar{a}^{T} x+\left\|P^{T} x\right\|_{2} \leq d$

Menurut Hertog et al. [20], formulasi robust counterpart (31) merupakan kendala conic quadratic programming (CQO). Robust counterpart dapat ditunjukkan dalam bentuk kendala $\mathrm{CQO}$, maka robust counterpart dapat dijamin computationally tractable.

\section{Metode Branch and Bound (B\&B)}

Merujuk pada Wolsey [21], perhatikan masalah mixed integer linear programing (MILP) dengan variabel biner berikut:

$\min \left\{z=c^{T} x: A x=b, x \geq 0, x \in\{0,1\}\right\}$
Penyelesaian masalah (32) dengan menggunakan metode B\&B dilakukan dalam beberapa tahap, pertama lakukan tahap relaksasi, yaitu selesaikan masalah MILP (32) sebagai masalah LP dengan mengabaikan kendala integer. Selanjutnya, sebut hasil relaksasi masalah LP tersebut sebagai $S^{1}$.

$S^{1}: \min \left\{z=c^{T} x: A x=b, x \geq 0\right\}$

dengan nilai optimal untuk fungsi objektifnya adalah $z^{1}$. Asumsikan bahwa solusi optimal dari $S^{1}$ belum seluruhnya integer. Hal ini berarti bahwa masalah MILP belum memiliki solusi optimal. Tetapi $z^{1}$ tetap digunakan sebagai batas bawah dalam masalah MILP tersebut, karena belum ada nilai $\bar{z}$ maka dilakukan inisiasi $\bar{z}=\infty$.

Tahap kedua adalah mempartisi daerah fisibel $S^{1}$ dengan mencabangkan pada salah satu variabel pecahan yang seharusnya bernilai integer dengan aturan branching. Branching dilakukan apabila $<\bar{z}$. Maka sekarang terdapat dua persamaan LP baru yaitu $S^{2} \operatorname{dan} S^{3}$.

$S^{2}: \min \left\{z=c^{T} x: A x=b, x \geq 0, x_{i}=0, x_{j} \in\right.$

$\{0,1\}, \forall j \in I\}$

$S^{3}: \min \left\{z=c^{T} x: A x=b, x \geq 0, x_{i}=1, x_{j} \in\right.$

$\{0,1\}, \forall j \in I\}$

Selesaikan $S^{2}$ dan $S^{3}$ untuk mendapatkan solusi optimal baru. Asumsikan bahwa solusi optimal dari $S^{2}$ dan $S^{3}$ masih terdapat pecahan, maka solusi tersebut masih tetap infisibel untuk masalah MILP (32).

Tahap ketiga adalah memilih salah satu dari $S^{2}$ dan $S^{3}$ serta mencabangkannya dengan menambah kendala baru. Setelah memilih node (daerah LP), cabangkan kembali node tersebut. Proses rangkaian mencabangkan dan menyelesaikan LP akan terus berlanjut sampai solusi integer didapat. Nilai $z$ dari node tersebut digunakan untuk menjadi batas atas $\bar{Z}$ pada masalah MLP. Pada poin ini bisa dilakukan eliminasi dari pertimbangan node-node dengan nilai $z$ yang tidak lebih baik dari batas atas, $\bar{z}<\underline{z^{i}}$, maka node-node itu dapat diabaikan (fathom) karena tidak mungkin untuk mendapatkan solusi integer yang lebih baik dari daerah LP yang telah dimiliki.

Dalam tahap fathoming bisa dilakukan apabila memenuhi salah satu kondisi di bawah ini: (1) Nilai optimal $z$ masalah LP tidak lebih baik dari batas atas yang ada, $\bar{Z}<\underline{z}^{i}$ (pruned by bound). (2) Masalah LP tersebut infisibel $x^{i}(L P)=\varnothing$ (pruned by infeasibility), (3) Solusi optimal LP node $z^{i}=$ $\min \left\{c^{T} x=x \in S^{i}\right\}$ bernilai integer, sehingga fisibel untuk masalah MILP (pruned by optimality). 


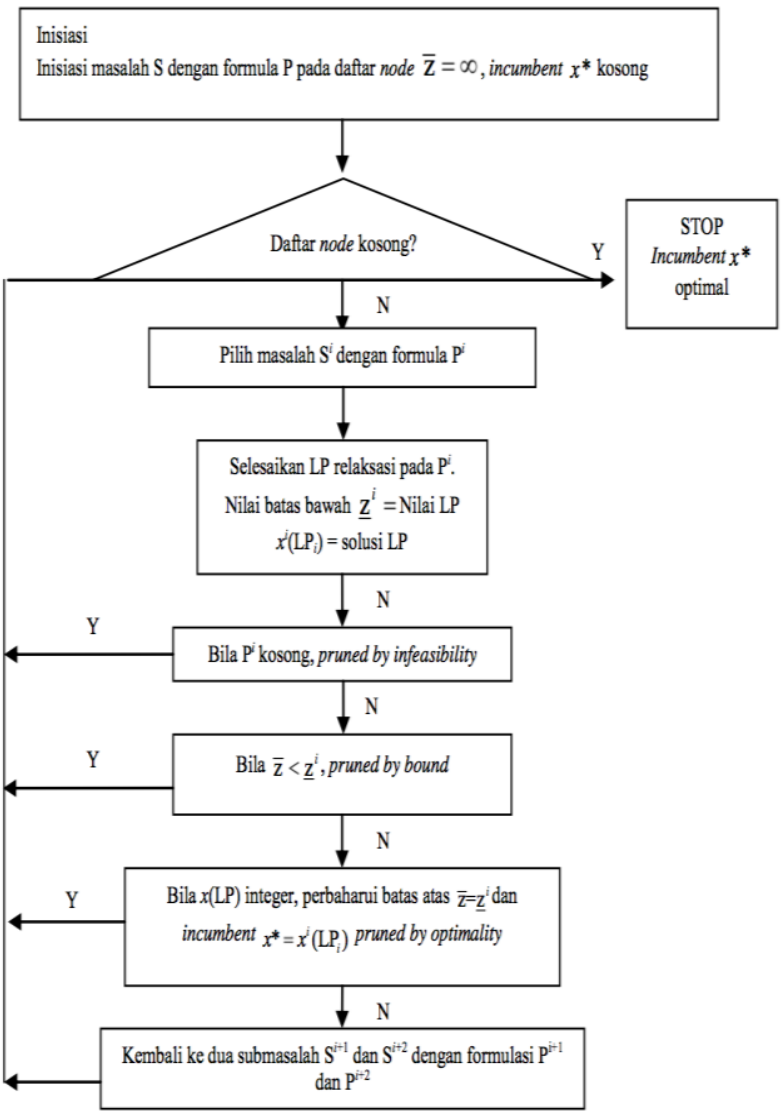

Gambar 2. Algoritma metode B\&B (Wolsey [21])

Tahap keempat adalah uji optimalitas, hentikan perhitungan jika tidak ada lagi submasalah yang belum diselesaikan dengan incumbent yang telah diperoleh. Lainnya ulang kembali algoritma B\&B dengan memilih node untuk pencabangan selanjutnya sampai semua node telah fathom. Node yang telah fathom dengan nilai $z$ paling kecil adalah solusi optimal untuk masalah MILP. Untuk lebih jelas perhatikan Algoritma Metode B\&B pada Gambar 2 (Wolsey [21]).

\section{Hasil dan Pembahasan}

Pada bagian hasil dan pembahasan dipaparkan bagaimana penentuan RC dengan memilih himpunan taktentu box dan ellipsoid untuk masalah penjadwalan ruang operasi di rumah sakit.

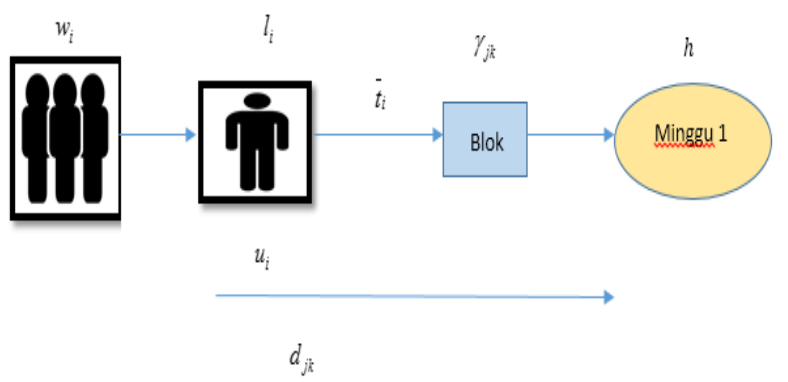

Gambar 3. Perencanaan ruang operasi

\section{Model Optimisasi Tak Tentu untuk Penjad- walan Ruang Operasi Rumah Sakit}

Merujuk pada Addis et al. [4], ilustrasi penjadwalan ruang operasi dengan tujuan meminimumkan total waktu tunggu pasien dapat dilihat pada Gambar 3.

Misal himpunan pasien elektif $I$ dijadwalkan pada $h$ banyaknya hari pada perencanaan horison. Banyaknya hari yang telah dihabiskan setiap pasien $i \in I$ pada saat berada di daftar tunggu dinotasikan dengan $w_{i}$. Setiap pasien memiliki maksimum waktu tunggu yang diijinkan selama $l_{i}$, urgensi dinotasikan dengan $u_{i}$, dan estimasi durasi operasi selama $t_{i}$.

Diasumsikan strategi yang digunakan adalah penjadwalan blok dan setiap blok merepresentasikan ruang operasi beserta hari kerjanya. Misal himpunan blok ruang operasi $J$ ditugaskan untuk masing-masing spesialisasi beserta jadwalnya dalam satu minggu $k \in K$ dengan $K$ himpunan minggu pada perencanaan horison dan total waktu yang tersedia $\gamma_{j k}$.

Berikut ini dibahas bagaimana pemodelan integer linear programming (ILP) digunakan untuk masalah penjadwalan ruang operasi rumah sakit.

Masalah ini dapat diformulasikan dengan menggunakan variable biner $x_{i j}^{k}$ yang bernilai 1 jika pasien $i$ dikirimkan pada blok $j$ pada minggu $k \in K$ dan bernilai 0 jika tidak memenuhi kriteria tersebut.

$x_{i j}^{k} \in\{0,1\}$

Fungsi objektif pada masalah ini adalah meminimumkan total waktu tunggu pasien,

$\min \sum_{i \in I}\left(\sum_{j \in J} \sum_{k \in K}\left[d_{j k}+\left(w_{i}+d_{j k}-l_{i}\right)^{+}\right] u_{i} x_{i j}^{k}+\right.$

$\left[\left(w_{i}+h+1\right)+\left(w_{i}+h+1-l_{i}\right)^{+}\right] u_{i}(1-$

$\left.\left.\sum_{j \in J} \sum_{k \in K} x_{i j}^{k}\right)\right)$

dimana

$\left(w_{i}+d_{j k}-l_{i}\right)^{+}=\max \left(w_{i}+d_{j k}-l_{i}, 0\right)$

adalah keterlambatan pasien (banyaknya waktu tunggu setelah waktu seharusnya). Perhatikan bahwa suku pertama dari fungsi objektif (37) menyatakan penalty untuk pasien yang terjadwal. Untuk setiap pasien $i$ yang terjadwal, penalty terdiri dari dua bagian, yaitu bagian pertama adalah banyaknya hari $d_{j k}$ yang digunakan sebelum menerima operasi pada perencanaan horison dan keterlambatan pasien $\left(w_{i}+d_{j k}-l_{i}\right)^{+}$. Bagian pertama ini diboboti dengan parameter urgensi $u_{i}$ untuk mem- 
berikan prioritas kepada pasien dengan kondisi paling darurat. Pada suku kedua berkaitan dengan pasien yang tidak terjadwal yakni jumlah keterlambatan $\left(w_{i}+h+1-l_{i}\right)^{+}=\max \left(w_{i}+h+1-\right.$ $\left.l_{i}, 0\right)$ dan keseluruhan waktu tunggu yang digunakan sebelum dan sesudah perencanaan horison awal. Keterlambatan dan waktu tunggu pasien dipengaruhi oleh parameter urgensi $u_{i}$.

Selanjutnya, fungsi kendala pertama merepresentasikan bahwa setiap pasien yang dioperasi paling banyak melakukan satu kali operasi.

$\sum_{j \in J} \sum_{k \in K} x_{i j}^{k} \leq 1, \forall i \in I$

Fungsi kendala kedua merepresentasikan total estimasi durasi operasi di blok $j$ pada minggu $k$ harus lebih kecil atau sama dengan maksimum waktu yang tersedia $\gamma_{j k}$.

$\sum_{i \in I} t_{i} x_{i j}^{k} \leq \gamma_{j k}, \forall j \in J, \forall k \in K$

Formulasi lengkap dari model ILP untuk penjadwalan ruang operasi rumah sakit adalah sebagai berikut.

$$
\begin{aligned}
& \min \sum_{i \in I}\left(\sum_{j \in J} \sum_{k \in K}\left[d_{j k}+\left(w_{i}+d_{j k}-l_{i}\right)^{+}\right] u_{i} x_{i j}^{k}+\right. \\
& {\left[\left(w_{i}+h+1\right)+\left(w_{i}+h+1-l_{i}\right)^{+}\right] u_{i}(1-} \\
& \left.\left.\sum_{j \in J} \sum_{k \in K} x_{i j}^{k}\right)\right) \\
& \text { s.d.h } \sum_{j \in J} \sum_{k \in K} x_{i j}^{k} \leq 1, \forall i \in I \\
& \sum_{i \in I} t_{i} x_{i j}^{k} \leq \gamma_{j k}, \forall j \in J, \forall k \in K \\
& x_{i j}^{k} \in\{0,1\}
\end{aligned}
$$

Selanjutnya, dalam makalah ini dibahas model penjadwalan ruang operasi rumah sakit, parameter yang melibatkan data tak tentu, dimana data taktentu tersebut adalah estimasi durasi operasi $t$. Formulasi model optimisasi robust untuk kasus ini adalah dengan menambahkan kendala $t_{i} \in U$ pada model ILP yang disajikan pada masalah (41) seperti dapat dilihat pada masalah (42).

$$
\begin{aligned}
& \min \sum_{i \in I}\left(\sum_{j \in J} \sum_{k \in K}\left[d_{j k}+\left(w_{i}+d_{j k}-l_{i}\right)^{+}\right] u_{i} x_{i j}^{k}+\right. \\
& {\left[\left(w_{i}+h+1\right)+\left(w_{i}+h+1-l_{i}\right)^{+}\right] u_{i}(1-} \\
& \left.\left.\sum_{j \in J} \sum_{k \in K} x_{i j}^{k}\right)\right) \\
& \text { s.d.h } \sum_{j \in J} \sum_{k \in K} x_{i j}^{k} \leq 1, \forall i \in I \\
& \sum_{i \in I} t_{i} x_{i j}^{k} \leq \gamma_{j k}, \forall j \in J, \forall k \in K \\
& x_{i j}^{k} \in\{0,1\}, t_{i} \in U
\end{aligned}
$$

Selanjutnya dalam makalah ini dibahas dua jenis himpunan tak tentu sesuai dengan Teorema 1, yaitu himpunan box uncertainty dan ellipsoidal uncertainty. Hal ini dilakukan untuk menjamin bahwa hasil pemodelan $\mathrm{RC}$ yang diperoleh berupa model optimisasi linear dan optimisasi konik kuadratik.

\section{Penentuan Robust Counterpart untuk Masa- lah Penjadwalan Ruang Operasi Rumah Sakit dengan Box Uncertainty Set}

Asumsikan bahwat $t_{i} \in U$, dimana $U$ merupakan box uncertainty set yang dapat dinyatakan sebagai

$t_{i}=\bar{t}_{i}+P_{i} \zeta_{i}$

dengan $\bar{t}_{i} \in R^{L}$ merupakan waktu nominal ke-i dan $P \in R^{n \times L}$ sebarang matriks berordo $n \times L$ dan $\zeta_{i} \in R^{L} \quad$ merupakan vektor taktentu. Sehingga kendala ketiga pada persamaan (42) dapat ditulis kembali menjadi:

$$
\begin{aligned}
\sum_{i \in I} & t_{i} x_{i j}^{k} \equiv \sum_{i \in I}\left(\bar{t}_{i}+P_{i} \zeta_{i}\right) x_{i j}^{k}=\sum_{i \in I} \bar{t}_{i} x_{i j}^{k}+P_{i} \zeta_{i} x_{i j}^{k} \\
& =\sum_{i \in I} \bar{t}_{i} x_{i j}^{k}+\max _{\zeta:\left|\zeta_{i}\right| \leq 1} P_{i} x_{i j}^{k} \zeta_{i}, \\
& =\sum_{i \in I} \bar{t}_{i} x_{i j}^{k}+\sum_{i \in I}\left|P_{i} x_{i j}^{k}\right|, \\
& <\gamma_{j k}
\end{aligned}
$$

dengan norm

$\left\|P_{i} x_{i j}^{k}\right\|_{1}=\sum_{i \in I}\left|P_{i} x_{i j}^{k}\right|$

maka (45) menjadi

$\sum_{i \in I} t_{i} x_{i j}^{k}=\sum_{i \in I} \bar{t}_{i} x_{i j}^{k}+\left\|\sum_{i \in I} P_{i} x_{i j}^{k}\right\|_{1} \leq \gamma_{j k}$

sehingga formulasi $R C$ untuk masalah penjadwalan ruang operasi dengan tujuan meminimumkan waktu tunggu pasien menggunakan himpunan box uncertainty dapat dilihat pada masalah (47).

$\min \sum_{i \in I}\left(\sum_{j \in J} \sum_{k \in K}\left[d_{j k}+\left(w_{i}+d_{j k}-l_{i}\right)^{+}\right] u_{i} x_{i j}^{k}+\right.$ $\left[\left(w_{i}+h+1\right)+\left(w_{i}+h+1-l_{i}\right)^{+}\right] u_{i}(1-$

$\left.\left.\sum_{j \in J} \sum_{k \in K} x_{i j}^{k}\right)\right)$

s.d.h $\sum_{j \in J} \sum_{k \in K} x_{i j}^{k} \leq 1, \forall i \in I$

$\sum_{i \in I} t_{i} x_{i j}^{k}=\sum_{i \in I} \bar{t}_{i} x_{i j}^{k}+\left\|\sum_{i \in I} P_{i} x_{i j}^{k}\right\|_{1} \leq \gamma_{j k}$

$x_{i j}^{k} \in\{0,1\}$

Perhatikan masalah (47) merupakan masalah dengan fungsi objektif dan kendala yang linear, namun melibatkan variable biner. Masalah (47) tidak lagi memiliki struktur semi-infinite dan fungsi kendala yang ada dapat dengan mudah dimodelkan sebagai satu himpunan kendala linear. Dengan demikian formulasi $R C$-box uncertainty (16) merupakan masalah optimisasi linear integer. Tractability dari RC-Box terjamin karena memenuhi paradigma optimisasi robust sebagaimana dibahas pada asumsi B.1-B.4.

Penyelesaian masalah optimisasi linier yang melibatkan variabel biner dapat diselesaikan dengan menggunakan Metode Branch and Bound (lihat Wolsey [21]). Pada makalah ini untuk perhitungan pada contoh kasus yang dibahas pada makalah ini, perhitungannya dibantu dengan menggunakan software Maple. 


\section{Penentuan Robust Counterpart untuk Masa- lah Penjadwalan Ruang Operasi Rumah Sakit Pendekatan Ellipsoidal Uncertainty Set}

Jenis himpunan kedua yang dapat digunakan dalam hal menjamin kondisi computationally tractability adalah dengan mengasumsikan bahwa himpunan durasi operasi merupakan data taktentu yang berada dalam himpunan ellipsoidal uncertainty. Seperti disebutkan oleh Gorissen et al. [19] dan Hertog et al. [20], isu computationally tractability ini merupakan isu penting dalam optimisasi robust.

Robustness terhadap $U$ dapat diformulasikan sebagai constraint-wise, maka setiap kendala yang melibatkan data tak tentu pada masalah penjadwalan ruang operasi rumah sakit, dapat diformulasikan sebagai berikut.

$$
\begin{aligned}
& \sum_{i \in I} t_{i} x_{i j}^{k} \equiv \sum_{i \in I}\left(\bar{t}_{i}+P_{i} \zeta_{i}\right) x_{i j}^{k}=\sum_{i \in I} \bar{t}_{i} x_{i j}^{k}+P_{i} \zeta_{i} x_{i j}^{k} \\
& \quad=\sum_{i \in I} \bar{t}_{i} x_{i j}^{k}+\max _{\zeta: \mid \zeta_{i} i_{2} \leq 1} P_{i} x_{i j}^{k} \zeta_{i} \\
& \quad \leq \gamma_{j k}
\end{aligned}
$$

Seperti telah dibahas pada bagian metode penelitian. Pertidaksamaan (48) dapat ditulis kembali sebagai berikut.

$$
\begin{aligned}
& \sum_{i \in I} t_{i} x_{i j}^{k} \equiv \sum_{i \in I}\left(\bar{t}_{i}+P_{i} \zeta_{i}\right) x_{i j}^{k}=\sum_{i \in I} \bar{t}_{i} x_{i j}^{k}+P_{i} \zeta_{i} x_{i j}^{k} \\
& \quad=\sum_{i \in I} \bar{t}_{i} x_{i j}^{k}+\max _{\zeta:\left|\zeta_{i}\right|_{2} \leq 1} P_{i} x_{i j}^{k} \zeta_{i} \\
& \quad=\sum_{i \in I} \bar{t}_{i} x_{i j}^{k}+\left\|\sum_{i \in I} P_{i} x_{i j}^{k}\right\|_{2} \leq \gamma_{j k}
\end{aligned}
$$

Dengan demikian, formulasi robust counterpart untuk kasus dengan ellipsoidal uncertainty set dapat ditulis sebagai formulasi (50).

$$
\begin{aligned}
& \min \sum_{i \in I}\left(\sum_{j \in J} \sum_{k \in K}\left[d_{j k}+\left(w_{i}+d_{j k}-l_{i}\right)^{+}\right] u_{i} x_{i j}^{k}+\right. \\
& {\left[\left(w_{i}+h+1\right)+\left(w_{i}+h+1-l_{i}\right)^{+}\right] u_{i}(1-} \\
& \left.\left.\sum_{j \in J} \sum_{k \in K} x_{i j}^{k}\right)\right) \\
& \quad \text { s.d.h } \sum_{j \in J} \sum_{k \in K} x_{i j}^{k} \leq 1, \forall i \in I \\
& \quad \sum_{i \in I} t_{i} x_{i j}^{k}=\sum_{i \in I} \bar{t}_{i} x_{i j}^{k}+\left\|\sum_{i \in I} P_{i} x_{i j}^{k}\right\|_{2} \leq \gamma_{j k} \\
& \quad x_{i j}^{k} \in\{0,1\}
\end{aligned}
$$

Perhatikan bahwa robust counterpart (50) memiliki fungsi objektif linear dan himpunan fungsi kendala yang memuat pertidaksamaan konik kuadratik sehingga formulasi RC-ellipsoidal (50) dengan menggunakan pendekatan ellipsoidal uncertainty dapat diklasifikasikan ke dalam masalah optimisasi yang terjamin sebagai masalah optimisasi konik kuadratik dengan variabel biner.

Keterlibatan variabel biner pada formulasi (50) dapat diatasi dengan menggunakan metode branch and bound yang merujuk pada Wolsey [21]. Dalam perhitungan contoh kasus yang disajikan, penyelesaian yang dibantu dengan software Maple, dalam hal ini karena terdapat fungsi kendala konik kuadratik, maka dalam perhitungan menggunakan software Maple.

\section{Data Penelitian dan Contoh Perhitungan}

Data yang digunakan dalam penelitian ini didapatkan dari data sekunder. Pada kasus ini, terdapat 10 pasien akan ditempatkan ke dalam empat blok ruang operasi yang tersedia pada rentang satu minggu. Data pasien berupa banyaknya hari yang digunakan pasien pada saat daftar tunggu $\left(w_{i}\right)$, maksimum waktu tunggu yang diijinkan tiap pasien $\left(l_{i}\right)$, urgensi tiap pasien $\left(u_{i}\right)$, dan estimasi durasi operasi tiap pasien $\left(t_{i}\right)$ serta nilai pengganggu $P$ dari setiap indeks $i$ dengan range dari 0 sampai 0,2083 hari (0 sampai 5 jam) berasal dari data acak yang didapatkan dengan simulasi numerik menggunakan aplikasi Maple syntax "rand (range)" dan "Generate (float(range,digits))". Pada penjadwalan blok yang tersedia khusus untuk spesialisasi THT (Telinga, Hidung, Tenggorokan) diambil dari Wulansari [25], lihat Tabel 1. penomoran block ruang operasi berdasarkan hari dan jam.

Hasil perhitungan dengan menggunakan model penjadwalan ruang operasi rumah sakit dengan model nominal ILP (Addis et al [4]), $R C$ pada penjadwalan ruang operasi rumah sakit dengan pendekatan box uncertainty serta ellipsoidal uncertainty dapat dilihat dalam Tabel 3 dengan waktu penyelesaian (CPU time) pada aplikasi Maple masingmasing 194 milidetik, 172 milidetik dan 511 milidetik.

Nilai fungsi objektif dari model nominal tanpa data taktentu, RC Box dan RC Ellipsoidal yang menunjukkan waktu tunggu pasien pada Tabel 3. Variabel keputusan yang bernilai 1 atau 0 , dapat digunakan untuk menentukan penjadwalan ruang operasi, Penjadwalan optimal penggunaan ruangan operasi yang menunjukkan utilitas dari ruang operasi dapat dilihat pada Tabel 4.

Tabel 1. Penjadwalan blok (Wulansari [25])

\begin{tabular}{cccc}
\hline $\begin{array}{c}\text { Nama ruang } \\
\text { operasi }\end{array}$ & Selasa & Rabu & Jumat \\
\hline Melati 1 & $08.00-15.30$ & $08.00-15.30$ & $08.00-15.30$ \\
Melati 2 & - & $08.00-15.30$ & - \\
\hline
\end{tabular}

Tabel 2. Data pasien - dalam hari(Wulansari [25])

\begin{tabular}{cccccl}
\hline Pasien $i$ & $w_{i}$ & $l_{i}$ & $u_{i}$ & $t_{i}$ & $P_{i}$ \\
\hline 1 & 12 & 7 & 1 & 0,0742 & 0,00601 \\
2 & 5 & 4 & 2 & 0,0506 & 0,08097 \\
3 & 1 & 25 & 5 & 0,0666 & 0,00079 \\
4 & 26 & 26 & 4 & 0,0932 & 0,00506 \\
5 & 11 & 1 & 5 & 0,0989 & 0,01173 \\
6 & 3 & 17 & 2 & 0,0461 & 0,03788 \\
7 & 5 & 19 & 3 & 0,0795 & 0,00966 \\
8 & 4 & 23 & 2 & 0,0645 & 0,00157 \\
9 & 26 & 10 & 4 & 0,0656 & 0,06153 \\
10 & 16 & 18 & 1 & 0,0964 & 0,00062 \\
\hline
\end{tabular}


Tabel 3. Nilai fungsi objektif dan solusi optimal untuk model ILP, RC-box dan RC-ellipsoidal uncertainty set

\begin{tabular}{|c|c|c|c|c|c|c|c|c|c|c|c|}
\hline \multicolumn{4}{|c|}{ Model Nominal ILP } & \multicolumn{4}{|c|}{$\begin{array}{c}\text { Robust counterpart dengan box } \\
\text { uncertainty }\end{array}$} & \multicolumn{4}{|c|}{$\begin{array}{l}\text { Robust counterpart dengan ellipsoidal } \\
\text { uncertainty }\end{array}$} \\
\hline Varial & putusan & $f$ & $\begin{array}{l}\text { CPU } \\
\text { Time }\end{array}$ & Variabe & utusan & $f$ & $\begin{array}{l}\text { CPU } \\
\text { Time }\end{array}$ & Variabe & eputusan & $f$ & CPU Time \\
\hline$x_{12}^{1}$ & 1 & \multirow{10}{*}{185 hari } & \multirow{10}{*}{$\begin{array}{c}194 \text { mili } \\
\text { detik }\end{array}$} & $x_{13}^{1}$ & 1 & \multirow{10}{*}{199 hari } & \multirow{10}{*}{$\begin{array}{c}172 \text { mili } \\
\text { detik }\end{array}$} & $x_{14}^{1}$ & 1 & \multirow{10}{*}{225 hari } & \multirow{10}{*}{$\begin{array}{c}511 \text { mili } \\
\text { detik }\end{array}$} \\
\hline$x_{21}^{1}$ & 1 & & & $x_{22}^{1}$ & 1 & & & $x_{21}^{1}$ & 1 & & \\
\hline$x_{32}^{1}$ & 1 & & & $x_{31}^{1}$ & 1 & & & $x_{31}^{1}$ & 1 & & \\
\hline$x_{41}^{1}$ & 1 & & & $x_{42}^{1}$ & 1 & & & $x_{42}^{1}$ & 1 & & \\
\hline$x_{51}^{1}$ & 1 & & & $x_{51}^{1}$ & 1 & & & $x_{52}^{1}$ & 1 & & \\
\hline$x_{63}^{1}$ & 1 & & & $x_{64}^{1}$ & 1 & & & $x_{62}^{1}$ & 1 & & \\
\hline$x_{72}^{1}$ & 1 & & & $x_{73}^{1}$ & 1 & & & $x_{73}^{1}$ & 1 & & \\
\hline$x_{82}^{1}$ & 1 & & & $x_{82}^{1}$ & 1 & & & $x_{81}^{1}$ & 1 & & \\
\hline$x_{91}^{1}$ & 1 & & & $x_{91}^{1}$ & 1 & & & $x_{94}^{1}$ & 1 & & \\
\hline$x_{103}^{1}$ & 1 & & & $x_{103}^{1}$ & 1 & & & $x_{103}^{1}$ & 1 & & \\
\hline
\end{tabular}

Tabel 4. Penjadwalan ruang operasi dengan untuk model nominal ILP, RC box uncertainty set dan RC ellipsoidal uncertainty set

\begin{tabular}{|c|c|c|}
\hline \multicolumn{3}{|c|}{ Penjadwalan ruang operasi dengan untuk model ILP } \\
\hline Ruang & Selasa $\quad$ Rabu & Jumat \\
\hline Melati 1 & 08.00-15.30: $\quad 08.00-15.30:$ & 09.00-15.30: \\
\hline \multirow{3}{*}{ Melati 2} & Pasien 2,4,5,9 Pasien $1,3,7,8$ & (kosong) \\
\hline & - $\quad$ 08.00-15.30: & \\
\hline & Pasien 6,10 & \\
\hline \multicolumn{3}{|c|}{$\begin{array}{l}\text { Penjadwalan ruang operasi dengan untuk model } \mathrm{RC} \\
\text { dengan box uncertainty set }\end{array}$} \\
\hline \multirow{3}{*}{ Melati 1} & $\begin{array}{ll}\text { Selasa } & \text { Rabu }\end{array}$ & Jumat \\
\hline & 08.00-15.30: & 09.00-15.30: \\
\hline & Pasien 3,5,9 Pasien 2,4,8 & Pasien 6 \\
\hline \multirow[t]{2}{*}{ Melati 2} & - $\quad$ 08.00-15.30: & \\
\hline & Pasien $1,7,10$ & \\
\hline \multicolumn{3}{|c|}{$\begin{array}{l}\text { Penjadwalan ruang operasi dengan untuk model } \mathrm{RC} \\
\text { dengan ellipsoidal uncertainty set }\end{array}$} \\
\hline \multirow{3}{*}{ Melati 1} & $\begin{array}{ll}\text { Selasa } & \text { Rabu }\end{array}$ & Jumat \\
\hline & 08.00-15.30: & 09.00-15.30: \\
\hline & Pasien 4,5,6 & Pasien 9,1 \\
\hline \multirow[t]{2}{*}{ Melati 2} & 08.00-15.30: & \\
\hline & Pasien 7,10 & \\
\hline
\end{tabular}

Dalam hal robustness, secara formulasi matematika maka dapat dilihat bahwa formulasi robust counterpart dari masalah optimisasi taktentu penjadwalan ruang operasi merupakan masalah optimisasi dengan tingkat computationally tractable yaitu linear optimisasi dan conic quadratic optimisasi.

Dapat dilihat dalam beberapa literatur (lihat BenTal dan Nemirovskii [15], Gorissen et al [19]) bahwa dengan pemilihan box dan ellipsoidal uncertainty set ini, maka masalah taktentu dari penjadwalan ruang operasi ini tidak lagi memuat kelas masalah yang semi-infinite. Perlu disebutkan bahwa formulasi RC sebagai linear dan conic quadratic optimisasi diperlukan untuk menjamin eksistensi solusi optimal global. Sehingga isu penting untuk memperoleh formulasi RC yang computationally tractable telah dipenuhi.

\section{Simpulan}

Sesuai dengan tujuan utama pembahasan dalam makalah ini, telah ditunjukkan bahwa formulasi RC yang diperoleh merupakan kelas masalah optimisasi yang computationally tractable. Contoh perhitungan yang dilakukan pada penerapan Robust Counterpart masalah penjadwalan ruang operasi rumah menunjukkan kondisi the best worst case untuk mengatasi ketidaktentuan yang terjadi. Sebagai saran pengembangan, dapat dirujuk Addis et al. [26] model yang telah dibahas dapat dikembangkan dengan mempertimbangkan rescheduling pasien elektif (nonemergensi) yang akan dioperasi. Artinya, menghilangkan asumsi bahwa jika pasien elektif (nonemergensi) yang terjadwal tidak dioperasi tepat dan sesuai dengan jadwal yang ditentukan maka ia akan dioperasi sehari setelah perencanaan berakhir. Selain itu, disarankan data perhitungan menggunakan data primer sehingga dimanfaatkan oleh pihak rumah sakit untuk mengevaluasi efisiensi ruang operasi yang tersedia agar waktu tunggu tiap pasien dapat diminimumkan. Rujuk Gorrisen et al. [19], model penjadwalan ruang operasi rumah sakit dengan ketidaktentuan estimasi durasi operasi juga dapat dikembangkan dengan asumsi data taktentu merupakan himpunan Polyhedral Uncertainty. Lebih lanjut dapat dipertimbangkan untuk mengkaji masalah sebagai masalah dengan dua tahap pengambilan keputusan dengan menggunakan metode Affinely Adjustable Robust Counterpart merujuk pada Gorissen et al. [19], Ben-Tal dan Nemirovskii [27] dan Ben-Tal et al. [28].

\section{Ucapan Terimakasih}

Penelitian ini didanai oleh Penelitian Berbasis Kompetensi DIKTI Tahun 2017 dengan Nomor Kontrak 718/UN6.3.1/PL/2017 dan didukung oleh bantuan literatur dari TWAS Individual Research Grant 2016-2017 untuk penulis pertama dengan nomor kontrak 15-253 RG/MATHS/AS_I. 


\section{Daftar Pustaka}

1. Barnes, C.D., Quiason, J.L., Benson, C., and McGuiness, D., Success Stories in Simulation in Health Care, Proceedings of the 1997 Winter Simulation Conference, 1997, pp. 1280-1285.

2. Tyler, D., Pasquariello, C., and Chen, C., Determining Optimum Operating Room Utilization, Anesthesia and Analgesia, 96(4), 2003, pp. 11141121.

3. Weiss, R., The Impact of Block Scheduling and Release Time on Operating Room Efficiency. Industrial Engineering, Clemson University, 2014.

4. Addis, B., Carello, G., and T'anfani, E., A Robust Optimization Approach for the Advanced Scheduling Problem with Uncertain Surgery Duration in Operating Room Planning - an Extended Analysis., Preprints, https://hal. archives-ouvertes.fr/hal-00936019, 2014, diakses tanggal 10 Februari 2017.

5. Denton, B., Viapiano, J., and Vogl, A., Optimization of Surgery Sequencing and Scheduling Decisions Under Uncertainty, Health Care Management Science, 10(1), 2007, pp. 13-24.

6. Min, D., and Yih, Y., Scheduling Elective Surgery Under Uncertainty and Downstream Capacity Constraints, European Journal of Operational Research, 206(3), 2010, pp. 642-652.

7. Oostrum, J.V., Houdenhoven, M.V., Hurink, J., Hans, E., Wullink, G., and Kazemier, G., A Mastersurgical Scheduling Approach for Cyclic Scheduling in Operating Room Departments, $O R$ Spectrum, 30, 2008, pp. 355-374.

8. Denton, B., Miller, J., Balasubramanian, H., and Huschka, Optimal Allocation of Surgery Blocks to Operating Rooms Under Uncertainty, Operations Research, 58, 2010, pp. 802-816.

9. Hans, E., Wullink, G., Houdenhoven, M.V., and Kamezier, G., Robust Surgery Loading, European Journal of Operational Research, 185, 2008, pp. 1038-1050.

10. T'anfani, E., Testi, A., and Alvarez, R., Operating Room Planning Considering Stochastic Surgery Durations. International Journal of Health Management and Information, 1(2), 2010, pp. 167-183.

11. Mulvey, J.M., Vanderbei, R.J., and Zenios, S.A., Robust Optimization of Large-Scale Systems, Operations research, 43(2), 1995, pp.264281.

12. Gabrel, V., Murat, C., and Thiele, A., Recent Advances in Robust Optimization: An Overview, European Journal of Operational Research, 235(3), 2014, pp. 471-483.
13. Ben-Tal, A., Nemirovski, A. Robust Solutions of Linear Programming Problems Contaminated with Uncertain Data, Mathematical Programming, 88(3), 2000, pp. 411-421.

14. Ben-Tal, A, and Nemirovski, A., Robust Optimization-Methodology and Applications, Mathematical Programming, 92(3), 2002, pp. 453-480.

15. Ben-Tal, A., El Ghaoui, L., and Nemirovski, A. Robust Optimization, ISBN: 9780691143682, Princeton Series in Applied Mathematics, 2009.

16. Bertsimas, D., and Sim, M., The Price of Robustness, Operations Research, 52(1), 2004, pp. 3553.

17. Bertsimas, D., Brown, D.B., and Caramanis, C., Theory and Application of Robust Optimization, SIAM Rev., 53(3), 2011, pp. 464-501.

18. Goerigk, M., and Schöbel, A., Algorithm Engineering in Robust Optimization, Algorithm Engineering, pp. 245-279, Springer International Publishing, 2016.

19. Gorissen, B.L., Yanikoglu, I., and Hertog, D.D., A Practical Guide to Robust Optimization, Omega: The International Journal of Management Science, 53, 2015, pp. 124-137.

20. Hertog, D.D., Ben-Tal, A., and Brekelmans, R. Practical Robust Optimization, Lecture Notes LNMB Course Spring 2015, Tilburg University, 2015.

21. Wolsey, L.A., Integer Programming, 42, New York: Wiley, 1998.

22. Chaerani, D., Roos, C., Handling Optimization under Uncertainty Problem Using Robust Counterpart Methodology, Jurnal Teknik Industri, 15(2), 2013, pp. 111-118.

23. Hunter, J.K., An Introduction to Real Analysis. Department of Mathematics, University of California at Davis., 2014.

24. Olver, P.J., Numerical Analysis Lecture Notes. Minnesota: University of Minnesota, 2008.

25. Wulansari, D., Penjadwalan Kamar Operasi Menggunakan Pemrograman Linear Bilangan Bulat. Skripsi Sarjana Institut Pertanian Bogor. 2012.

26. Addis, B., Carello, G., Grosso, A., T`anfani, E., $A$ Rolling Horison Framework for the Operating Rooms Planning under Uncertain Surgery Duration, Preprints, 2014, https://hal.archives-ouvertes.fr/hal-00936085, diakses tanggal 10 Februari 2017.

27. Ben-Tal, A., Goryashko, A., Guslitzer, E., and Nemirovski, A., Adjustable Robust Solutions of Uncertain Linear Programs, Mathematical Programming, 99(2), 2008, pp. 351-376.

28. Ben-Tal, A., and Nemirovski, A., Selected Topics in Robust Convex Optimization, Mathematical Programming, 112(1), 2008, pp. 125-158. 